\title{
Trigeminal nerve stimulation: a recently approved treatment approach in attention deficit hyperactivity disorder
}

\author{
Mazlum Çöpür ${ }^{1 *}$ (D) and Sidar Çöpür²
}

\begin{abstract}
Attention-deficit hyperactivity disorder (ADHD) with its high prevalence is a growing area of concern and research, whereas exact underlying pathophysiology remains unknown. Behavioral therapy and multiple medications include methylphenidate, atomoxetine, and amphetamines while trigeminal nerve stimulator (TNS) is the first medical device in ADHD with FDA approval. The aim of this article is to evaluate the latest studies in this field.
\end{abstract}

Keywords: Attention-deficit hyperactivity disorder, Treatment, Trigeminal nerve

To the Editor,

\section{Introduction}

As a common psychiatric condition affecting $2-18 \%$ of the population between ages 2 and 17 , attentiondeficithyperactivity disorder (ADHD) is characterized by impulsivity, inattention, and hyperactivity while three subtypes as predominantly hyperactive-impulsive, predominantly inattentive, and combined have been identified. Additionally, ADHD cases generally do not resolve with age and affect $4-5 \%$ of adults [1].

\section{Main text}

Even though the exact underlying pathophysiology remains unknown, defects at the neurotransmitter systems of dopamine and norepinephrine primarily at the prefrontal cortex, cerebellum, and caudate nucleus have been implicated. Defects at presynaptic inhibition of dopamine release mediated via D2/D3 and dopamine transporter-1 which are associated with inattention and disorganized behavior have been implicated in the pathophysiology of ADHD [2,3]. In addition to behavioral therapy, Food and Drug Administration-approved

\footnotetext{
* Correspondence: sidar1996@yahoo.com.tr

${ }^{1}$ Department of Psychology, Arel University, Istanbul, Turkey

Full list of author information is available at the end of the article
}

pharmacotherapies include stimulants such as methylphenidate and amphetamines and others such as atomoxetine, guanfacine, and clonidine [3]. Patients are considered treatment refractory after unsuccessful administration of two psychostimulant trials which approximately comprises more than $15-20 \%$ of cases [4]. Additionally, the use of ADHD medications is contraindicated in certain conditions, mainly symptomatic cardiovascular diseases, and limited due to various adverse effects. Trigeminal nerve stimulator (TNS) is the first medical device in ADHD with FDA approval (obtained in 2019) and indicated in children at age 7-12 without ongoing ADHD pharmacotherapy [5]. The use of TNS in neuropsychiatric disorders is not limited to ADHD and includes epilepsy, depression, pain disorders, and migraine [6, 7].

The first study examining TNS in patients with ADHD is conducted by McGough et al. in 2015 which involves twenty-four participants at age 7-14 who received TNS treatment (bilateral stimulation of supraorbital branch of the trigeminal nerve for 7-9 $\mathrm{h}$ per night with a frequency of $120 \mathrm{~Hz}$ at cycles of $30 \mathrm{~s}$ on and $30 \mathrm{~s}$ off) during sleep for 8 weeks. Improvements at inattention and hyperactivity symptoms have been recorded which are assessed via the ADHD-IV Rating Scale/parent-completed Conners Global Index/Parent-completed Behavior
Springer Open (c) The Author(s). 2021 Open Access This article is licensed under a Creative Commons Attribution 4.0 International License, which permits use, sharing, adaptation, distribution and reproduction in any medium or format, as long as you give appropriate credit to the original author(s) and the source, provide a link to the Creative Commons licence, and indicate if changes were made. The images or other third party material in this article are included in the article's Creative Commons licence, unless indicated otherwise in a credit line to the material. If material is not included in the article's Creative Commons licence and your intended use is not permitted by statutory regulation or exceeds the permitted use, you will need to obtain permission directly from the copyright holder. To view a copy of this licence, visit http://creativecommons.org/licenses/by/4.0/. 
Rating Inventory of Executive Functioning/Computerized Attention Network Task Incongruent Reaction Time [8]. Furthermore, the first double-blindplacebocontrolled randomized controlled trial is conducted by McGough et al. in 2019 in which sixty-two participants at age 8-12 have been assigned to either active TNS treatment or sham device for 4 weeks. The same TNS protocol was applied as in the first study. Both groups demonstrated improvement in ADHD-IV Rating Scale scores at the first week while improvement only persisted in the active TNS group in addition to significant improvement at parent-completed Conners Global Index (not observed at sham group) [9]. However, it is crucial to acknowledge the relatively high cost of TNS device and issues that may lead to non-compliance over time including not being easy to use.

\section{Conclusion}

Studies investigating the mechanism of action of TNS are scarce and non-comprehensive; however, the current approach is as follows: When the supraorbital branch of the ophthalmic branch of the trigeminal nerve is stimulated, the impulse is carried into the cerebral hemispheres and brainstem at which change in excitability of neurons occurs [4]. Neuroimaging studies confirm the altered neuronal activity at the thalamus, insula, amygdala, hippocampus, and precentral gyrus after TNS $[10,11]$. The lack of withdrawal symptoms or druginduced emotional liability appears to be the strengths of the TNS approach while beneficial effects obtained with TNS are abruptly reversible after discontinuation similar to stimulatory drugs $[12,13]$. The use of TNS is not recommended in children with implantable pacemakers or insulin pumps while adverse effect profile is relatively safe by including insomnia, teeth clenching, and headache. User-friendliness of such treatment option is essential for compliance of patients, though non-compliance may be an issue in ADHD patients receiving TNS device therapy. Patches of TNS device, disposable silver gel patches, should be placed by parents on the forehead of children and removed each morning. The aim is to stimulate the supraorbital branch of the ophthalmic nerve (cranial nerve $\mathrm{V}_{1}$ ) while signals with a $120-\mathrm{Hz}$ frequency and a $250-\mu$ s pulse width are applied with a cycle of $30 \mathrm{~s}$ on and $30 \mathrm{~s}$ off $[8,9]$. However, a cycle of $5 \mathrm{~s}$ on and $5 \mathrm{~s}$ off is also recommended in few studies [14]. Although comprehensive studies about the efficiency of TNS in ADHD are lacking, TNS appears to be a valid option especially for treatment-refractory cases with no apparent adverse effect. Therefore, it is important for physicians to be aware of such recently approved treatment option for ADHD.

\section{Abbreviations}

ADHD: Attention-deficit hyperactivity disorder; TNS: Trigeminal nerve stimulator

\section{Acknowledgements}

None

\section{Authors' contributions}

$M C$ has contributed to the study design, literature search, and preparation of the manuscript. SÇ has contributed to the preparation of manuscript and literature search. All authors have read and approved the final version of the manuscript.

\section{Funding}

None

Availability of data and materials

Not applicable

\section{Declarations}

Ethics approval and consent to participate

Not applicable

Consent for publication

Not applicable

Competing interests

The authors declare that they have no competing interests.

\section{Author details}

${ }^{1}$ Department of Psychology, Arel University, Istanbul, Turkey. ${ }^{2}$ Department of Medicine, Koc University School of Medicine, Istanbul, Turkey.

Received: 10 January 2021 Accepted: 11 July 2021

Published online: 26 July 2021

References

1. Berger I. Diagnosis of attention deficit hyperactivity disorder: much ado about something. Isr Med Assoc J. 2011;13(9):571-4.

2. Sharma A, Couture J. A review of the pathophysiology, etiology, and treatment of attention-deficit hyperactivity disorder (ADHD). Ann Pharmacother. 2014;48(2):209-25. https://doi.org/10.1177/106002801351 0699.

3. Golmirzaei J, Mahboobi H, Yazdanparast M, Mushtaq G, Kamal MA, Hamze E. Psychopharmacology of attention-deficit hyperactivity disorder: effects and side effects. Curr Pharm Des. 2016;22(5):590-4. https://doi.org/10.21 74/1381612822666151124235816

4. Shim S-H, Yoon H-J, Bak J, Hahn S-W, Kim Y-K. Clinical and neurobiological factors in the management of treatment refractory attention-deficit hyperactivity disorder. Prog Neuropsychopharmacol Biol Psychiatry. 2016;70: 237-44. https://doi.org/10.1016/j.pnpbp.2016.04.007.

5. Voelker R. Trigeminal nerve stimulator for ADHD. JAMA. 2019;321(21):2066.

6. Shiozawa P. Silva MEd, Carvalho TCd, Cordeiro Q, Brunoni AR, Fregni F. Transcutaneous vagus and trigeminal nerve stimulation for neuropsychiatric disorders: a systematic review. Arq Neuropsiquiatr. 2014;72(7):542-7. https:// doi.org/10.1590/0004-282X20140061.

7. Shiozawa P, Cordeiro Q, Cho HJ, Trevizol AP, Brietzke E. A critical review of trials of transcranial direct current stimulation and trigeminal nerve stimulation for depression: the issue of treatment-emergent mania. Trends Psychiatry Psychother. 2017;39(1):48-53. https://doi.org/10.1590/2237-6089-2 016-0027.

8. McGough JJ, Loo SK, Sturm A, Cowen J, Leuchter AF, Cook IA. An eightweek, open-trial, pilot feasibility study of trigeminal nerve stimulation in youth with attention-deficit/hyperactivity disorder. Brain Stimul. 2015;8(2): 299-304. https://doi.org/10.1016/j.brs.2014.11.013.

9. McGough JJ, Sturm A, Cowen J, Tung K, Salgari GC, Leuchter AF, et al. Double-blind, sham-controlled, pilot study of trigeminal nerve stimulation for attention-deficit/hyperactivity disorder. J Am Acad Child Adolesc Psychiatry. 2019;58(4):403-11.e3. 
10. Fanselow EE. Central mechanisms of cranial nerve stimulation for epilepsy. Surg Neurol Int. 2012;3(Suppl 4):S247-S54. https://doi.org/10.4103/21527806.103014.

11. Gadeyne S, Bourgeois A, Boon P, Carrette E, Carrette S, Raedt R, Vonck K. The effect of trigeminal nerve stimulation (TNS) on the noradrenergic signaling in the brains of healthy volunteers. In: 6 TH BELGIAN BRAIN CONGRESS: THE GENE-ENVIRONMENT TANGO IN THE HEALTHY AND DISEAS ED BRAIN 2016 (p. 219781).

12. Soss J, Heck C, Murray D, Markovic D, Oviedo S, Corrale-Leyva G, et al. A prospective long-term study of external trigeminal nerve stimulation for drug-resistant epilepsy. Epilepsy Behav. 2015;42:44-7. https://doi.org/10.101 6/j.yebeh.2014.10.029.

13. Blader JC, Pliszka SR, Jensen PS, Schooler NR, Kafantaris V. Stimulantresponsive and stimulant-refractory aggressive behavior among children with ADHD. Pediatrics. 2010;126(4):e796-806. https://doi.org/10.1542/peds.2 010-0086.

14. Zare M, Salehi M, Mahvari J, Najafi MR, Moradi A, Pour MH, et al. Trigeminal nerve stimulation: a new way of treatment of refractory seizures. Adv Biomed Res. 2014;3:81.

\section{Publisher's Note}

Springer Nature remains neutral with regard to jurisdictional claims in published maps and institutional affiliations.

\section{Submit your manuscript to a SpringerOpen ${ }^{\circ}$ journal and benefit from:}

- Convenient online submission

- Rigorous peer review

- Open access: articles freely available online

- High visibility within the field

- Retaining the copyright to your article

Submit your next manuscript at $\boldsymbol{\nabla}$ springeropen.com 